Relations industrielles

Industrial Relations

\title{
Rethinking the Future of Work: Directions and Visions, by Colin C. Williams, New York: Palgrave, 2007, 343 pp., ISBN 978-1-4039-9371-7.
}

\section{Tony Gould}

Volume 63, numéro 2, 2008

URI : https://id.erudit.org/iderudit/018580ar

DOI : https://doi.org/10.7202/018580ar

Aller au sommaire du numéro

Éditeur(s)

Département des relations industrielles de l'Université Laval

ISSN

0034-379X (imprimé)

1703-8138 (numérique)

Découvrir la revue

Citer ce compte rendu

Gould, T. (2008). Compte rendu de [Rethinking the Future of Work: Directions and Visions, by Colin C. Williams, New York: Palgrave, 2007, 343 pp., ISBN 978-1-4039-9371-7.] Relations industrielles / Industrial Relations, 63(2), 365-366. https://doi.org/10.7202/018580ar

Tous droits réservés (C Département des relations industrielles de l'Université Laval, 2008
Ce document est protégé par la loi sur le droit d'auteur. L’utilisation des services d'Érudit (y compris la reproduction) est assujettie à sa politique d'utilisation que vous pouvez consulter en ligne.

https://apropos.erudit.org/fr/usagers/politique-dutilisation/ 


\title{
Recensions
}

\section{Book Reviews}

\author{
Rethinking the Future of Work: Directions and Visions, \\ by Colin C. Williams, New York: Palgrave, 2007, 343 pp., ISBN \\ 978-1-4039-9371-7.
}

Colin Williams' book Rethinking the Future of Work is not for the fainthearted. He sets himself a daunting task covering a formidable array of work practices, social issues and work theories.

Williams' book lays out visions and philosophies on the work environment globally as it unfolds into the $21^{\text {st }}$ century. In the process, he addresses the views held by an array of commentators: those who see doom and gloom ahead and others who are not so pessimistic. Williams contends that many contemporary publications on future work practice do not appropriately acknowledge and address previous literature on this subject. Indeed, he says that some authors, particularly those in the "guru" category, tend to gather-up and rebadged various bits and pieces of works by serious scholars and present them as their own. It is Williams' view that theories forecasting the future must be built on solid principles of past work practices. He asks how the future of work may be explored: should we stick with the same approaches, techniques and strategies previously utilized or should we do something different.

This book contends that, although there are many conflicting arguments on the future of work, the methodology used by some scholars is similar. The principal common thread running through their arguments is based on economics. As a result of this, their conclu- sions are often not dissimilar. Williams' view is that this way of addressing the subject is over simplistic. It is flawed as it ignores a multitude of divergent elements that must be carefully examined in all of their complexities if this issue is to be seriously debated.

Williams visits the writing of many authors whose approaches, over a period of time, have assumed an importance that is unwarranted in his opinion. He contends that there is no one-size-fitsall model and that different societies, geographical locations, ethnic backgrounds and the like will always need to be factored in to any equation on the future of work. He highlights three points which need to be examined in the context of our global, contemporary, real world situation. These elements address the delivery of goods and services and comprise the following components: "the market" (private sector); "the State" (public sector); and the "informal/community sector". He goes on to say that for many commentators the future of work will mean stricter formalization through the market and the State, with the market sector ultimately being triumphant by achieving an open deregulated world economy through globalization. Although this theory is just that, "theory" not "fact", this does not deter numerous economists from viewing globalization as the yardstick by which all societies are measured with the First World being regarded as 
advanced and the Third World regarded as backward. By this measure, informal work in Third World countries does not rate at all. However, interestingly, when probed it would appear that formalization of work in the future is by no means the only way to go and capitalism may not ultimately takeover the public and informal/community sectors of world economy. Thus, it is argued that globalization is not inevitable and it is only one way (Western Society's way, principally) of looking at a multifaceted diverse work-future.

We know that there are multiple trajectories in lived practice insofar as work is concerned. We know, too, that work is based on many influences and not simply on an "industrial" society or a "post-industrial/information/ knowledge" society. Nevertheless, the dominant narratives in the book (from a wide range of contributors) generally favour either one side or the other. Each "side" begins with an approach containing some dualism and then develops its vision so that, ultimately, just one path is remaining. Following such a path is not in line with lived practice and may well lead us in the wrong direction.

Williams' book gives an initial impression that the future of work has, at its foundation, work-practices of the past. However, it goes on to say that we are not experiencing continuity only, but change as well: change that has multiple manifestations that are dependent on geographic, socio-economic and economic issues. Globalization is readily identified as being one of the many forces shaping the future. But not the only one. In tandem with it there are issues like localization and informalization. This means, obviously, that there's not one but many "futures" of work. There is no single future on this issue which is definitive: that is not subject to change.

The vast majority of people throughout the world do not control their own destiny, as there are powerful vested interests, political and corporate, that have influences upon their futures. In affluent societies, people generally have many work choices but the majority of people globally are not in this comfortable position.

Rethinking the Future of Work: Directions and Visions by Colin Williams is thought provoking, profound and based on sound research. It is well crafted and I recommend it to anyone who is interested in, among other things, helping to shape the future for those people throughout the world who are not empowered to do it for themselves.

Tony Gould

Consultant on Arts Management, Queensland, Australia

\section{Le développement durable comme compromis : la modernisation écologique de l'économie à l'ère de la mondialisation, par Corinne Gendron, Québec : Presses de l'Université du Québec, 2006, 276 p., ISBN 2-7605-1412-9.}

Largement connu depuis la publication du Rapport Brundtland, en 1987, le concept de développement durable est maintenant retenu et promu par la communauté des États comme le nouveau modèle de développement, lequel n'est plus seulement économique, mais capable de réconcilier équitablement et dans la durée le développement social et économique dans le respect de l'environnement. Depuis, le concept de développement durable et le nouveau projet de société proposé ont fait couler beaucoup d'encre et soulevé une grande variété de débats théoriques, politiques, économiques, sociologiques, écologiques, etc. 